\author{
THE SYNTHESIS OF \\ 4-DEOXYPYRIDO[1',2'-1,2]IMIDAZO[5,4-c]RIFAMYCIN SV \\ DERIVATIVES \\ Mario Brufani, Luciano Cellai ${ }^{\dagger}$, Egidio Marchi ${ }^{\dagger}$ \\ and Annalaura Segre ${ }^{\dagger}$ \\ Gruppo di Chimica Biologica e Strutturistica Chimica, Università "La Sapienza", \\ 00185 Roma, Italy \\ 'Istituto di Strutturistica Chimica "G. Giacomello" C.N.R. \\ C. P. 10-00016 Monterotondo Stazione, Roma, Italy \\ ${ }^{+\dagger}$ Alfa Farmaceutici S.p.A. \\ Via Ragazzi del '99, 5, 40133 Bologna, Italy \\ (Received for publication May 29, 1984)
}

\begin{abstract}
Two series of new semisynthetic rifamycin SV derivatives have been prepared. One of them bears a quaternary ammonium salt at $C_{3}(\mathbf{1} \sim 5)$, and the other a pyridoimidazo system condensed at $\mathrm{C}_{3}$ and $\mathrm{C}_{4}(\mathbf{6} \sim 11)$. While compounds $1 \sim 5$ had poor antibacterial activity in vitro, compounds $\mathbf{6} \sim \mathbf{1 1}$ were found to be highly active in vitro but poorly absorbed in vivo. They could thus have potential as agents in the therapy of intestinal infections.

The synthesis and the ${ }^{1} \mathrm{H}$ NMR structure determination of these new compounds are reported.
\end{abstract}

A new semisynthetic rifamycin, 4-deoxy-4'-methylpyrido[1',2'-1,2]imidazo[5,4-c]rifamycin SV, denoted either as rifamycin L 105 or as rifaximin, (Scheme 1) (6) has recently been synthesized by Alfa Farmaceutici, Bologna, Italy, and is now undergoing clinical trials as a topical intestinal disinfectant ${ }^{1}$. The new drug displays high antibacterial activity in vitro and it is very poorly absorbed when given per os. The first step in seeking a new rifamycin endowed with such pharmacokinetic properties was to prepare a series of 3-quaternary ammonium bromide derivatives of rifamycin SV (1 $\sim \mathbf{5})$. Probably because of their highly polar nature these derivatives displayed low antibacterial activity in vitro, especially on Gram-negative bacteria. A second series of compounds (6 11) was then prepared, of the type 4-deoxypyrido[1',2'-1,2]imidazo[5,4-c]rifamycin SV derivatives, which included the above mentioned rifamycin L 105 (6). These had the desired properties.

The synthesis and the physico-chemical characterization of these two new series of rifamycins are reported in this paper. The isolation and characterization of the reduced form of a reaction product intermediate to the formation of 6 , is also reported. It illustrates the mechanism of reaction leading to compounds $\mathbf{6} \sim 11$.

\title{
Chemistry
}

Compounds $\mathbf{1} \sim \mathbf{5}$ (Scheme 1) were prepared by prolonged heating of 3-bromorifamycin $\mathrm{S}^{2)}$ with an excess of the tertiary amine in chloroform. The products were obtained directly as a mixture of both the $\mathrm{S}$ and $\mathrm{SV}$ forms of the derivatives ${ }^{3)}$. In the case of $\mathbf{1}$, the $\mathrm{S}$ form was very unstable, giving 3-diethylaminorifamycin $\mathbf{S}^{4)}$. The products were either completely reduced with ascorbic acid, or directly separated and purified by column chromatography on silica gel. The S and SV forms of each derivative were interconvertible by reduction-oxidation with ascorbic acid- $\mathrm{K}_{3} \mathrm{Fe}(\mathrm{CN})_{6}$, respectively ${ }^{3)}$. They were characterized by elemental analysis and ${ }^{1} \mathrm{H}$ NMR as shown in Tables 1,2 and 3. The SV forms, which 
Scheme 1.

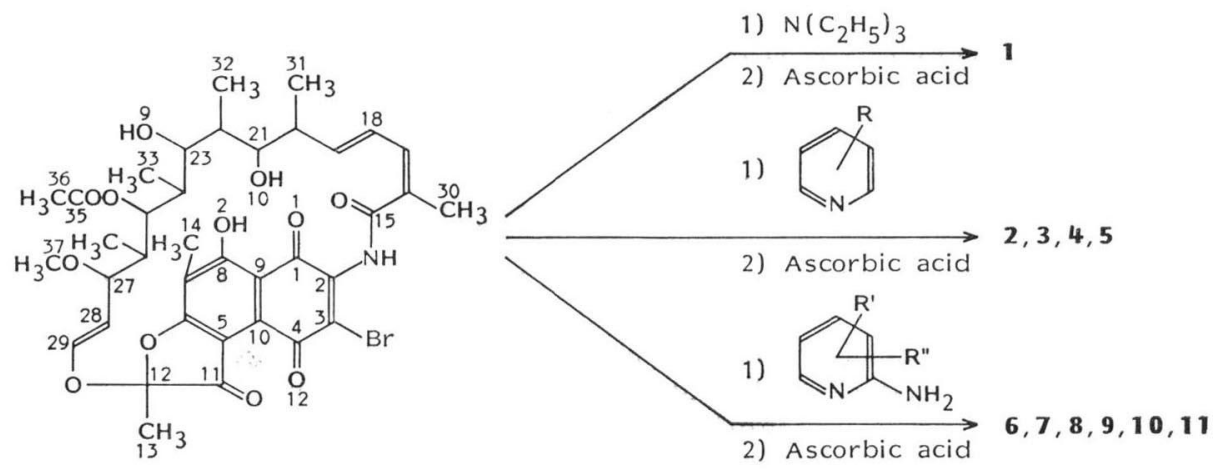

3-Bromorifamycin $\mathrm{S}$

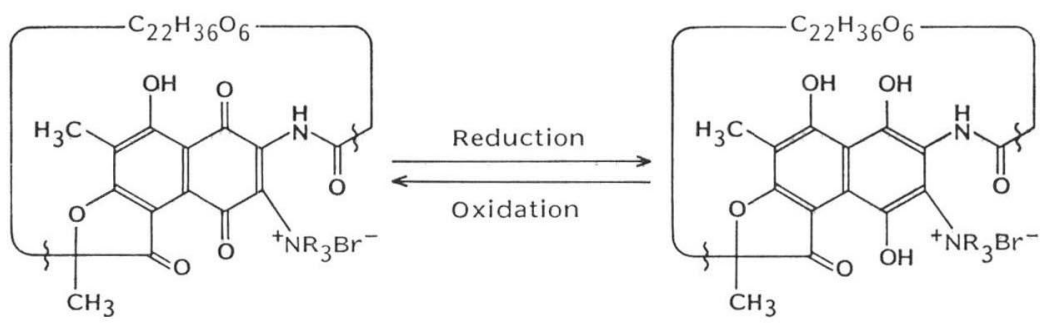

(s form)

$1 \sim 5$

SV form

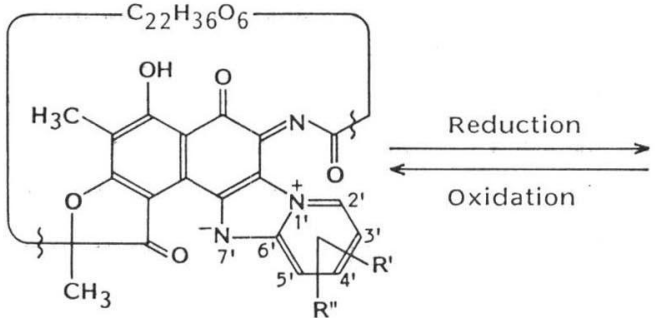

( $\mathrm{S}$ form)

$6 \sim 11$

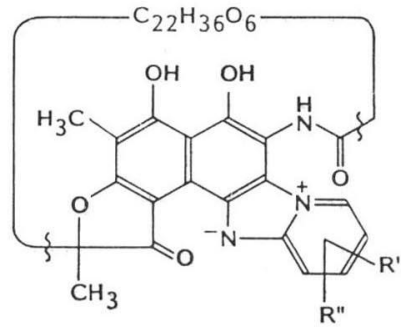

SV form

4-Deoxypyrido [ $\left.1^{\prime}, 2^{\prime}-1,2\right]$ imidazo$[5,4-c]$ rifamycin SV derivatives

are more stable and more water soluble, were tested in vitro on several bacterial strains and were all found to be inactive, especially toward Gram-negative bacteria ${ }^{1)}$, probably because their highly polar nature prevents them from being absorbed through the bacterial cell wall.

Compounds 6 11 (Scheme 1) were prepared by reacting one equivalent of 3-bromorifamycin $\mathrm{S}$ with two equivalents of the appropriate 2-aminopyridine derivative, at room temperature, for two hours. The reaction products were obtained in the $\mathrm{S}$ form, in good yields. They were then reduced to the SV form with ascorbic acid. Both S and SV forms were purified by column chromatography on silica gel. All compounds $(6 \sim 11)$ were very active on bacteria in vitro $^{1)}$. Compounds $6 \sim 11$ were characterized by elemental analysis and by ${ }^{1} \mathrm{H}$ NMR (Tables $1 \sim 3$ ). It is significant that compounds $\mathbf{6} \sim 11$ in the $\mathrm{S}$ form 
Table 1. Yields and elemental analysis of compounds $1 \sim 11$.

\begin{tabular}{|c|c|c|c|c|c|}
\hline $\begin{array}{l}\text { Compound } \\
\text { (SV form) }\end{array}$ & Reacting group & Formula & MW & $\begin{array}{c}\text { Yield } \\
(\%)\end{array}$ & Analyses $^{a}$ \\
\hline 1 & $\mathrm{~N}\left(\mathrm{C}_{2} \mathrm{H}_{5}\right)_{3}$ & $\mathrm{C}_{43} \mathrm{H}_{61} \mathrm{~N}_{2} \mathrm{O}_{12} \mathrm{Br}$ & 877.87 & 55 & $\mathrm{CHNBr}$ \\
\hline 2 & & $\mathrm{C}_{42} \mathrm{H}_{51} \mathrm{~N}_{2} \mathrm{O}_{12} \mathrm{Br}$ & 855.79 & 80 & $\mathrm{CHNBr}$ \\
\hline 3 & & $\mathrm{C}_{46} \mathrm{H}_{59} \mathrm{~N}_{2} \mathrm{O}_{12} \mathrm{Br}$ & 911.89 & 80 & $\mathrm{CHNBr}$ \\
\hline 4 & & $\mathrm{C}_{44} \mathrm{H}_{53} \mathrm{~N}_{2} \mathrm{O}_{14} \mathrm{Br}$ & 913.82 & 30 & $\mathrm{CHNBr}$ \\
\hline 5 & & $\mathrm{C}_{43} \mathrm{H}_{52} \mathrm{~N}_{3} \mathrm{O}_{13} \mathrm{Br}$ & 898.80 & 30 & $\mathrm{CHNBr}$ \\
\hline 6 & & $\mathrm{C}_{43} \mathrm{H}_{51} \mathrm{~N}_{3} \mathrm{O}_{11}$ & 785.89 & 85 & $\mathrm{CHN}$ \\
\hline 7 & & $\mathrm{C}_{43} \mathrm{H}_{51} \mathrm{~N}_{3} \mathrm{O}_{11}$ & 785.89 & 85 & $\mathrm{CHN}$ \\
\hline 8 & & $\mathrm{C}_{43} \mathrm{H}_{51} \mathrm{~N}_{3} \mathrm{O}_{11}$ & 785.89 & 85 & $\mathrm{CHN}$ \\
\hline 9 & & $\mathrm{C}_{49} \mathrm{H}_{55} \mathrm{~N}_{3} \mathrm{O}_{12}$ & 877.99 & 50 & $\mathrm{CHN}$ \\
\hline 10 & & $\mathrm{C}_{46} \mathrm{H}_{51} \mathrm{~N}_{3} \mathrm{O}_{11}$ & 821.23 & 45 & $\mathrm{CHN}$ \\
\hline 11 & & $\mathrm{C}_{42} \mathrm{H}_{49} \mathrm{~N}_{3} \mathrm{O}_{11}$ & 771.87 & 85 & $\mathrm{CHN}$ \\
\hline
\end{tabular}

a The elements are indicated for which the elemental analysis was carried out and resulted in agreement with calculated values within $\pm 0.3 \%$.

lack the amidic proton, the chromophore rings having assumed an orthoquinonimine structure, as is shown also by the X-ray analysis of one related derivative ${ }^{5)}$. Furthermore, the X-ray analysis ${ }^{5)}$ and an $\mathrm{N}_{1 \mathrm{~s}}$ ESCA study ${ }^{\mathrm{b})}$ revealed that charged forms make a large contribution to the resonance structure of the pyridoimidazo system.

Among this latter group of compounds, 6 was chosen for clinical evaluation. This compound was studied in greater detail. Among other things, it was observed that, by reacting only one equivalent of 2-amino-4-methylpyridine, it was possible to isolate a product which, upon adding either a further equivalent of amine, or of sodium bicarbonate, or merely by allowing it to remain in solution, gave 6 (S form). This compound was reduced with ascorbic acid and characterized by ${ }^{1} \mathrm{H}$ NMR. The reduced form, 12, was stable and not directly transformable into 6 ( $\mathrm{SV}$ form). The structure of 12 was assigned as illustrated in Scheme 2 and Fig. 1, and shows that the first step of the reaction is an attack of the amino group at $\mathrm{C}_{4}$, in agreement with the explanation proposed for closely related systems in an earlier study ${ }^{7)}$. 
Table 2. (A) $200 \mathrm{MHz}{ }^{1} \mathrm{H}$ NMR structure determination of compounds $\mathbf{1} \sim \mathbf{5}$ in the $\mathrm{SV}$ form, in $\mathrm{CDCl}_{3}$.

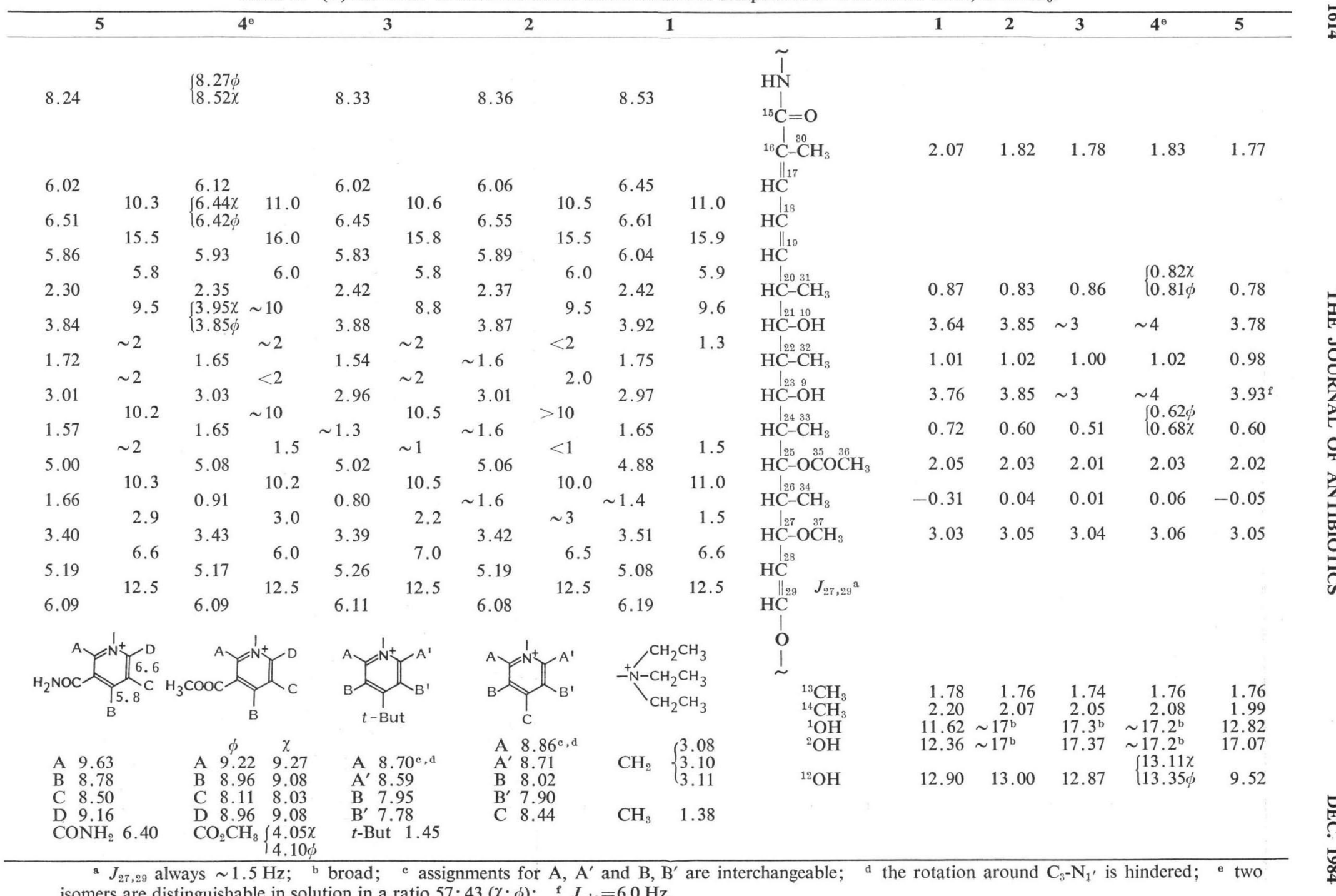


Table 2. (B) $200 \mathrm{MHz}{ }^{1} \mathrm{H}$ NMR structure determination of compounds $2 \sim 5$ in the $\mathrm{S}$ form, in $\mathrm{CDCl}_{3}$.

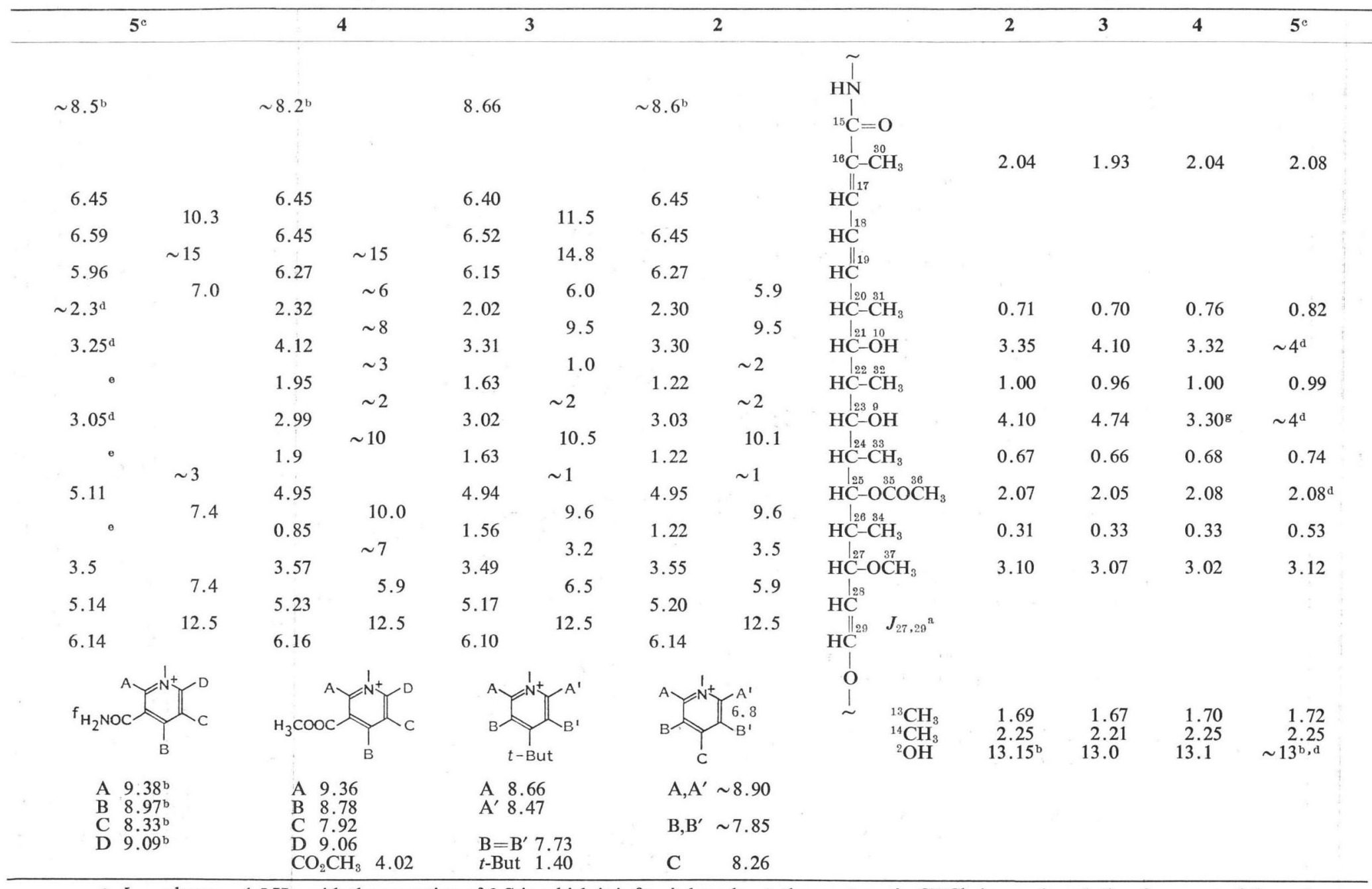

a $J_{27,29}$ always $\sim 1.5 \mathrm{~Hz}$, with the exception of 3-S in which it is $0 ;{ }^{\mathrm{b}}$ broad; ${ }^{\mathrm{c}}$ the spectrum in $\mathrm{CDCl}_{3}$ is very broad, therefore most of the assi-

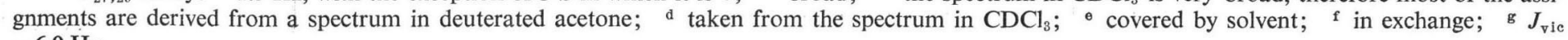
$=6.0 \mathrm{~Hz}$. 
Table 3. (A) $200 \mathrm{MHz}{ }^{1} \mathrm{H}$ NMR structure determination of

\begin{tabular}{|c|c|c|c|c|c|c|c|c|c|c|c|}
\hline \multicolumn{2}{|c|}{11} & \multicolumn{2}{|c|}{10} & \multicolumn{2}{|c|}{9} & \multicolumn{2}{|c|}{8} & \multicolumn{2}{|c|}{7} & \multicolumn{2}{|c|}{6} \\
\hline 8.36 & & 9.80 & & 9.05 & & 9.07 & & 8.84 & & 8.15 & \\
\hline 6.36 & & 6.37 & & 6.31 & & 6.36 & & 6.35 & & 6.43 & \\
\hline 6.82 & 10.3 & 6.91 & 10.5 & 6.76 & 10.9 & 6.84 & & 6.75 & & 6.88 & 11.0 \\
\hline 6.10 & 6.6 & $\begin{array}{l}6.02 \\
2.26\end{array}$ & $\begin{array}{l}13.3 \\
\sim 6\end{array}$ & $\begin{array}{l}5.98 \\
2.26\end{array}$ & $\begin{array}{r}15.7 \\
6.4\end{array}$ & 6.05 & 6.6 & 6.10 & 6.6 & 6.18 & 7.0 \\
\hline 3.61 & 9.6 & 3.65 & 9.5 & 3.62 & 9.6 & 3.66 & 8.8 & 3.57 & 10.3 & 3.68 & 10.0 \\
\hline 1.58 & $<2$ & 1.53 & & 1.56 & & 1.59 & $<1$ & 1.54 & $<2$ & & 2.0 \\
\hline 2.86 & $\begin{array}{l}\sim 2 \\
10.3\end{array}$ & 2.82 & $\begin{array}{r}2.2 \\
10.3\end{array}$ & 2.85 & $\begin{array}{l}\sim 2 \\
10.3\end{array}$ & 2.87 & $\begin{array}{r}2.2 \\
10.3\end{array}$ & 2.83 & $\begin{array}{r}2.3 \\
10.3\end{array}$ & 2.95 & 11.0 \\
\hline $\begin{array}{l}1.30 \\
4.87\end{array}$ & $<2$ & $\begin{array}{l}1.39 \\
4.92\end{array}$ & $<2$ & $\begin{array}{l}1.30 \\
4.88\end{array}$ & & $\begin{array}{l}1.39 \\
4.92\end{array}$ & $<2$ & $\begin{array}{l}1.24 \\
4.85\end{array}$ & $<2$ & $\begin{array}{l}1.43 \\
4.95\end{array}$ & $\sim 1$ \\
\hline 1.16 & $\begin{array}{r}11.0 \\
1.5\end{array}$ & 1.20 & $\begin{array}{r}10.3 \\
1.5\end{array}$ & & $\begin{array}{r}10.5 \\
2.0\end{array}$ & & $\begin{array}{r}10.6 \\
1.5\end{array}$ & 1.06 & $\begin{array}{r}10.3 \\
1.5\end{array}$ & 1.31 & $\begin{array}{l}10.0 \\
\sim 1\end{array}$ \\
\hline 3.31 & 5.9 & 3.36 & $\sim 5$ & 3.28 & 6.0 & 3.35 & 5.2 & 3.27 & 5.9 & 3.38 & 6.0 \\
\hline $\begin{array}{l}5.01 \\
6.05\end{array}$ & 12.5 & $\begin{array}{l}5.02 \\
6.02\end{array}$ & 12.5 & $\begin{array}{l}5.03 \\
6.03\end{array}$ & 12.5 & $\begin{array}{l}5.04 \\
6.05\end{array}$ & 12.5 & $\begin{array}{l}5.00 \\
6.04\end{array}$ & 12.5 & $\begin{array}{l}5.08 \\
6.15\end{array}$ & 12.5 \\
\hline
\end{tabular}

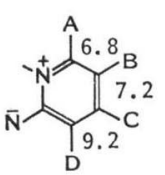
A 8.60
B 7.25
C 7.86
D 7.69<smiles>[B]c1c(C)c(N)c2c(N)c(F)c(F)c(C)c2c1C</smiles>

A 8.50

B 7.52

$\mathrm{C}, \mathrm{D}, \mathrm{E}, \mathrm{F} \sim 8.0$<smiles>[2H]c1c(N)c(OCc2c(N)c(C)c(Br)c(C)c2O)c(F)c(F)c1F</smiles>

A 8.32

B 7.13

C 7.20

$\mathrm{D}, \mathrm{D}^{\prime}, \mathrm{E}$,

$\mathrm{E}^{\prime} \sim 7.5$<smiles>Cc1nc(N)c(C)c2c1CC2</smiles>

A 8.60

B 7.25

C 7.71

$\mathrm{CH}_{3} 2.77$<smiles>Cc1c(N)nc(I)c(C)c1Br</smiles><smiles>Cc1nc(N)c(C)c(I)c1C</smiles>

A 8.37

A 8.45

B 7.10

C 7.35

C 7.54

$\mathrm{CH}_{3} 2.45$

$\mathrm{CH}_{\mathbf{f}} \quad\left\{\begin{array}{l}5.38 \\ 5.47\end{array}\right.$

${ }^{\mathrm{a}} J_{27,29}$ always $\sim 1.5 \mathrm{~Hz} ; \quad$ b broad; ${ }^{\mathrm{c}}$ not observed; ${ }^{\mathrm{d}} J_{\mathrm{v} 1 \mathrm{c}}=4.8 \mathrm{~Hz} ; \quad{ }^{\mathrm{e}} J_{\mathrm{vlc}} 5.5=\mathrm{Hz} ; \quad{ }^{\mathrm{f}} J_{\mathrm{gem}}=-12.2 \mathrm{~Hz}$.

Synthesis

\section{Standard Procedures}

$1 \mathrm{mmol}$ of 3-bromorifamycin $\mathrm{S}^{2)}$ was reacted with $5 \mathrm{mmol}$ of amine for compounds $\mathbf{1} \sim \mathbf{5}$ and with $2 \mathrm{mmol}$ of amine for compounds $\mathbf{6} \sim \mathbf{1 1}$, in $20 \mathrm{ml}$ of chloroform, under stirring, for 4 hours at reflux for compounds $1 \sim 5$, and for 2 hours at room temperature $\left(20 \sim 25^{\circ} \mathrm{C}\right)$ for compounds $6 \sim 11.5 \mathrm{ml}$ of chloroform were then added and the resulting solution was washed twice with $30 \mathrm{ml} 0.1 \mathrm{~N} \mathrm{HCl}$, and twice with water, dried over anhydrous sodium sulfate, filtered and evaporated. The residue was dissolved in 
compounds $\mathbf{6} \sim 11$ in the SV form, in $\mathrm{CDCl}_{3}$.

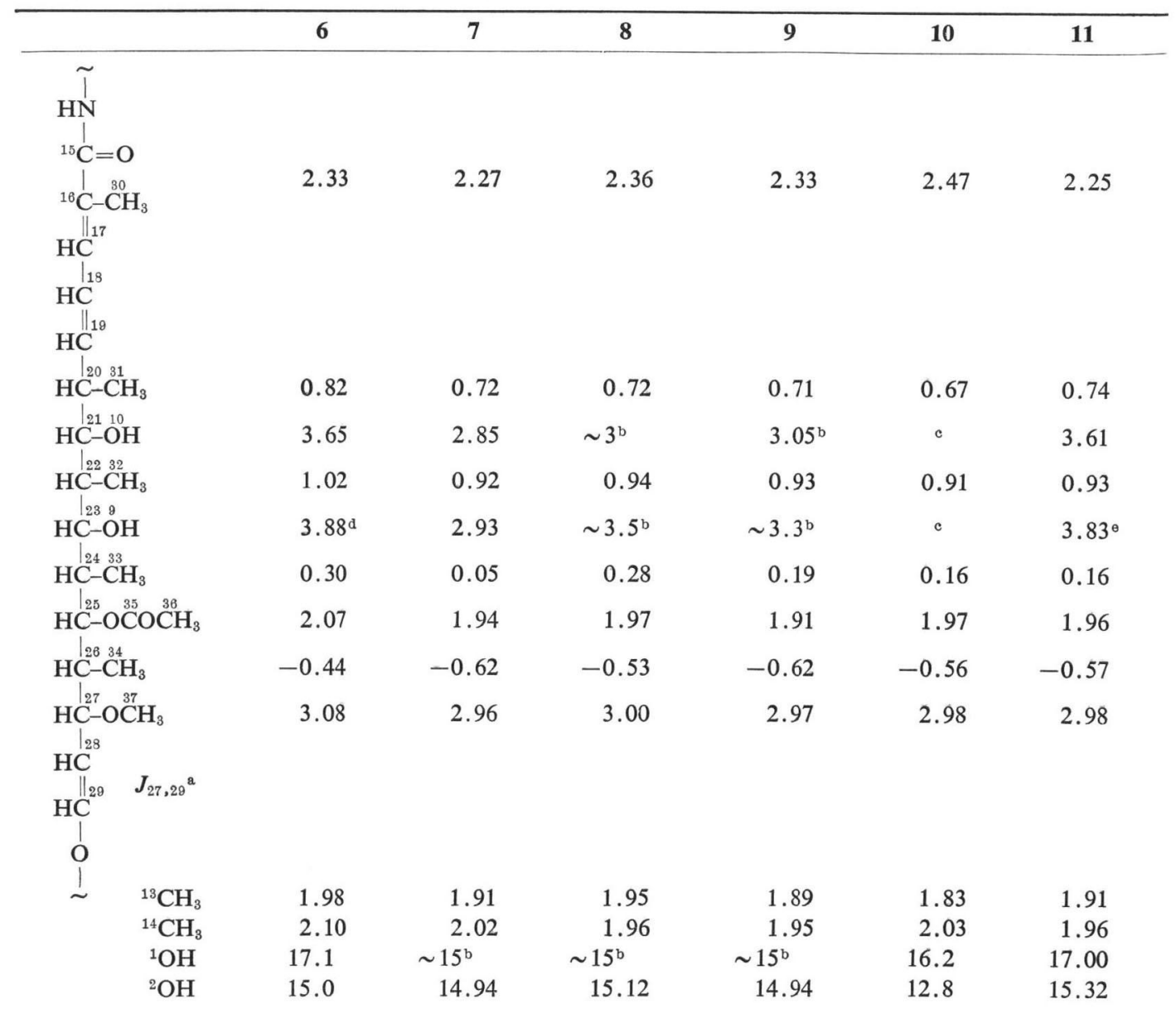

$20 \mathrm{ml}$ methanol, and $3 \mathrm{ml}$ of $25 \%$ aqueous L-( + -ascorbic acid were added. After 15 minutes stirring at room temperature the solution was added with $50 \mathrm{ml}$ chloroform, washed with water, dried over anhydrous sodium sulfate, filtered, and evaporated. The residue was then purified by column chromatography on $40 \mathrm{~g}$ of Silica gel 60, 40 63 $\mu \mathrm{m}$, eluting with mixtures of chloroform - methanol, 95: 5 90: 10 . Average yields; $50 \%$ for compounds $1 \sim 5$ and $80 \%$ for compounds $6 \sim 11$. Each compound was identified by ${ }^{1} \mathrm{H}$ NMR and by elemental analysis (Tables 1, 2 and 3 ). 
Table 3. (B) $200 \mathrm{MHz}{ }^{1} \mathrm{H}$ NMR structure determination

\begin{tabular}{llllll}
\hline 11 & 10 & 9 & 8 & 7 & 6
\end{tabular}

\begin{tabular}{|c|c|c|c|c|c|c|c|c|c|c|c|}
\hline 6.58 & 08 & 6.60 & & 6.60 & & 6.62 & & 6.4 & & & \\
\hline 6.64 & 9.8 & 6.60 & & 6.60 & & 6.55 & 11.0 & $\uparrow$ & & 6.6 & \\
\hline 6.48 & 15.5 & 6.50 & $\sim 5$ & 6.46 & & 6.45 & 15.5 & 6.8 & & & \\
\hline 2.32 & & 2.28 & 10.3 & 2.22 & 9.6 & 2.25 & 9.6 & $\sim 2.3$ & $\sim 10$ & 2.20 & 10.0 \\
\hline 1.58 & $<2$ & 1.75 & & 1.40 & $<2$ & $\begin{array}{r}2.87 \\
\sim 1.3\end{array}$ & & $\begin{aligned} & 2.92 \\
\sim & 1.6\end{aligned}$ & & $\begin{array}{l}2.93 \\
1.40\end{array}$ & $\sim 1$ \\
\hline 2.86 & $\begin{array}{r}1.5 \\
10.0\end{array}$ & 2.75 & $\begin{array}{r}2.0 \\
10.3\end{array}$ & 2.86 & $\begin{array}{l}\sim 2 \\
11.0\end{array}$ & 2.86 & 9.6 & 2.85 & $\begin{array}{l}\sim 2 \\
\sim 10\end{array}$ & 2.87 & 10.5 \\
\hline 1.34 & $<2$ & 1.38 & $<1$ & 1.32 & $<1$ & $\begin{array}{r}\sim 1.3 \\
4.77\end{array}$ & $<1$ & $\begin{array}{r}\sim 1.3 \\
4.78\end{array}$ & $\sim 2$ & 4.78 & $\sim 1$ \\
\hline 1.25 & $\begin{array}{r}10.4 \\
1.4\end{array}$ & 1.17 & $\begin{array}{r}10.3 \\
2.0\end{array}$ & 1.25 & $\begin{array}{r}10.3 \\
1.5\end{array}$ & 1.24 & $\begin{array}{r}10.3 \\
1.5\end{array}$ & $\sim 1.3$ & $\begin{array}{l}10.3 \\
\sim 2\end{array}$ & 1.25 & 11.0 \\
\hline 5.35 & 6.0 & 5.38 & 6.6 & 5.35 & 5.9 & 5.36 & 6.6 & 5.35 & 6.0 & $\begin{array}{l}3.55 \\
5.34\end{array}$ & 6.2 \\
\hline 6.31 & 12.5 & 6.36 & 12.5 & 6.32 & 12.5 & 6.36 & 12.5 & 6.32 & 12.5 & 6.32 & 12.5 \\
\hline
\end{tabular}

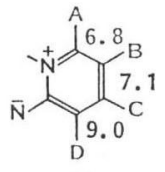

$J$

AC 1.2

AD 0.9

BD 1.1
A 9.47
B 7.16
C 7.56
D 8.07
C,D,E,F
$\sim 7.8$

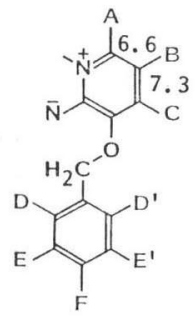

A 9.16

B 7.37
A $\quad 9.11$

B $\quad 7.00$

C 6.91

$J_{\mathrm{AC}}=1.5$

D, $\mathrm{D}^{\prime} \quad 7.58$

E, E',F 7.40

$\mathrm{CH}_{2} \quad 5.80^{\mathrm{b}}$<smiles>Cc1c(N)nc(I)c(Br)c1C</smiles>

A 9.32

B 7.07

C 7.36

$\mathrm{CH}_{3} 2.81$<smiles>Cc1nc(N)c(C)c(C)c1C</smiles>

A 9.27

B 7.40

C 7.89

$\mathrm{CH}_{3} 2.41$<smiles>Cc1c(N)nc(I)c(Br)c1C</smiles>

A 9.30

B 6.99

C 7.88

$\mathrm{CH}_{3} 2.51$

a $J_{27,28}$ always $\sim 1.5 \mathrm{~Hz} ; \quad{ }^{\mathrm{b}}$ non-equivalent protons giving resonances differing for $1 \mathrm{~Hz} ; \quad{ }^{\circ} J_{\mathrm{vic}}=4.5 \mathrm{~Hz}$;

\section{Crystallization Solvents}

Chloroform - $n$-hexane for compounds $\mathbf{1} \sim \mathbf{5}$ and ethanol - water for compounds $\mathbf{6} \sim \mathbf{1 1}$. Indeterminate melting points indicate decomposition on heating.

${ }^{1} \mathrm{H}$ NMR Analysis

${ }^{1} \mathrm{H}$ NMR spectra were recorded on the Brucker WP 200 (200 MHz) spectrometer of C.N.R.-Area della Ricerca di Roma. The signals were listed in ppm (TMS resonance $0.00 \mathrm{ppm}$ ) and the $J$ coupling constants in $\mathrm{Hz}$. 
of compounds $\mathbf{6} \sim \mathbf{1 1}$ in the $\mathrm{S}$ form, in $\mathrm{CDCl}_{3}$.

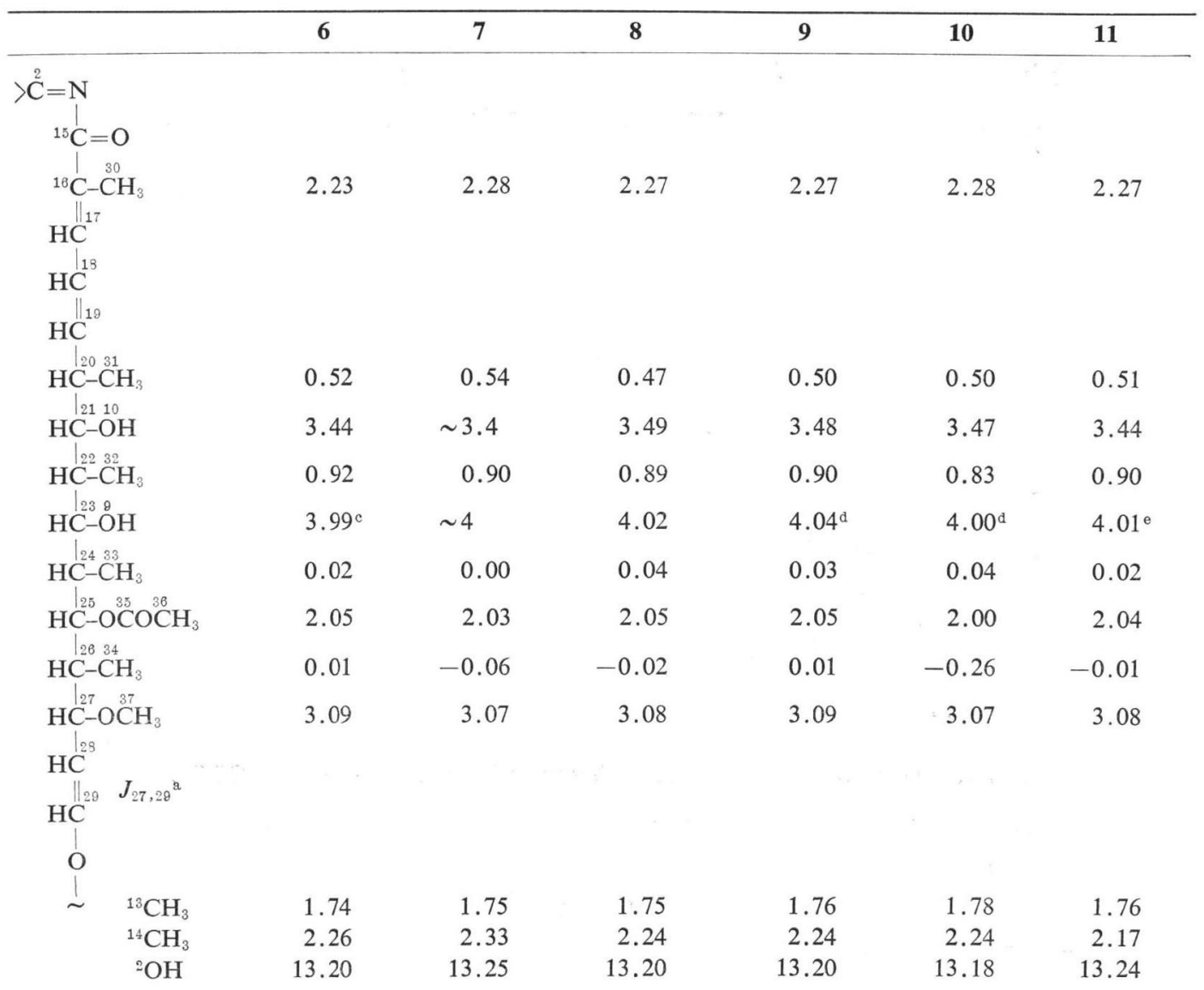

d $J_{\text {vic }}=3.7 \mathrm{~Hz} ; J_{\text {vic }}=3.6 \mathrm{~Hz}$

The spectra of the compounds in both the oxidized S and the reduced SV forms were assigned by extensive spin decoupling, based upon earlier NMR studies performed on several 3-substituted rifamycin $\mathrm{S}$ and $\mathrm{SV}$ derivatives ${ }^{8}$. Four spectra are discussed here in some detail, one for each series of new derivatives.

\section{3-Pyridiniumbromide Rifamycin SV (2-SV)}

Two isomers are present in $\mathrm{CDCl}_{3}$ solution in a ratio 95: 5. The major isomer displays a $\mathrm{C}_{30}-\mathrm{H}_{3}$ signal upfield shifted with respect to its usual resonance ${ }^{8)}$. 
Scheme 2.

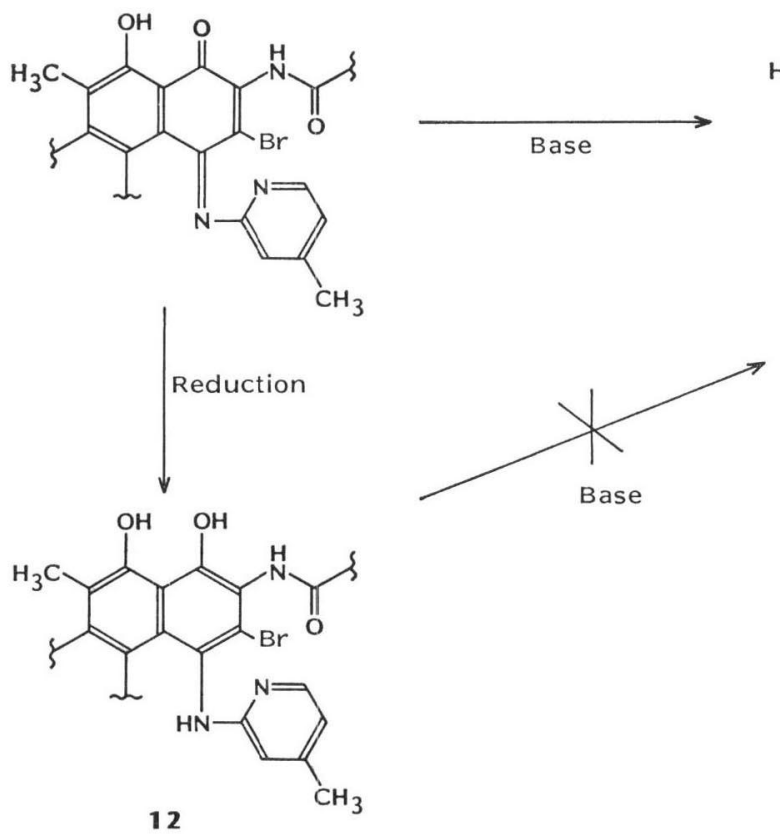<smiles></smiles>

6

Fig. 1. $200 \mathrm{MHz}{ }^{1} \mathrm{H}$ NMR structure determination of compound 12 in $\mathrm{CDCl}_{3}$.

$\begin{array}{lllllllllllll}6.26 & 6.72 & 5.99 & 2.35 & 3.93 & 1.83 & 3.03 & 1.63 & 5.37 & 1.26 & 3.48 & 5.05 & 6.12\end{array}$

$\sim 11 \sim 15 \quad 6.5 \sim 9$

$\sim 10<1 \quad 10.5$

5.512 .5

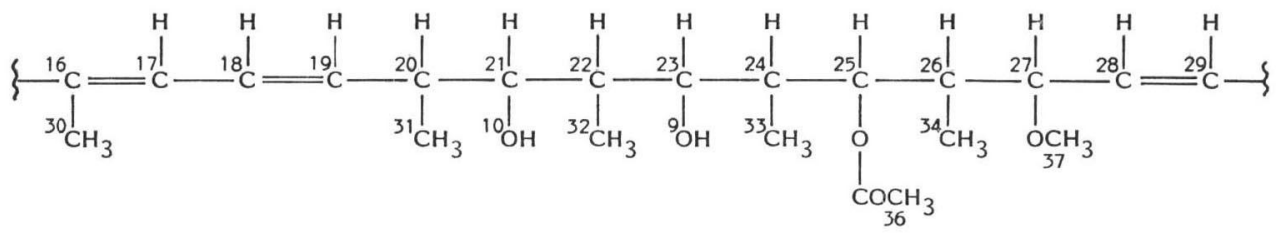

1.95

$\begin{array}{lllll}0.98 & \sim 3.5 & 1.04 & \sim 3.5 & 0.69\end{array}$

$0.03 \quad 3.08$

2.08<smiles></smiles>

$\begin{array}{cc}{ }^{13} \mathrm{CH}_{3} & 1.74 \\ { }^{14} \mathrm{CH}_{3} & 2.04 \\ { }^{1} \mathrm{NH} & \sim 8.3 \\ { }^{2} \mathrm{NH} & 11.15 \\ { }^{1} \mathrm{OH} & 12.97 \\ { }^{2} \mathrm{OH} & 16.25 \\ { }_{\mathrm{A}} & 7.07 \\ \mathrm{~B} & 6.64 \\ \mathrm{C} & 6.99\end{array}$

The resonance position of $\mathrm{C}_{18} \mathrm{H}(6.5 \mathrm{ppm})$ indicates that the amide carbonyl is transoid with respect to $\mathrm{C}_{2}-\mathrm{C}_{3}{ }^{8}$ ) and the $\mathrm{C}_{27} \mathrm{H}-\mathrm{C}_{28} \mathrm{H}$ dihedral angle is about $140^{\circ}{ }^{8}$. . All pyridinic protons are non-equivalent, and this loss of symmetry can be accounted for by a hindered rotation around $\mathrm{C}_{3}-\mathrm{N}_{1}$, They are downfield shifted, with respect to the corresponding protons in pyridine, due to the magnetic anisotropy of 
Fig. 2. $200 \mathrm{MHz}{ }^{1} \mathrm{H}$ NMR spectrum of compound 6-SV, $0.1 \mathrm{~mm}$ in $\mathrm{CDCl}_{3}$.

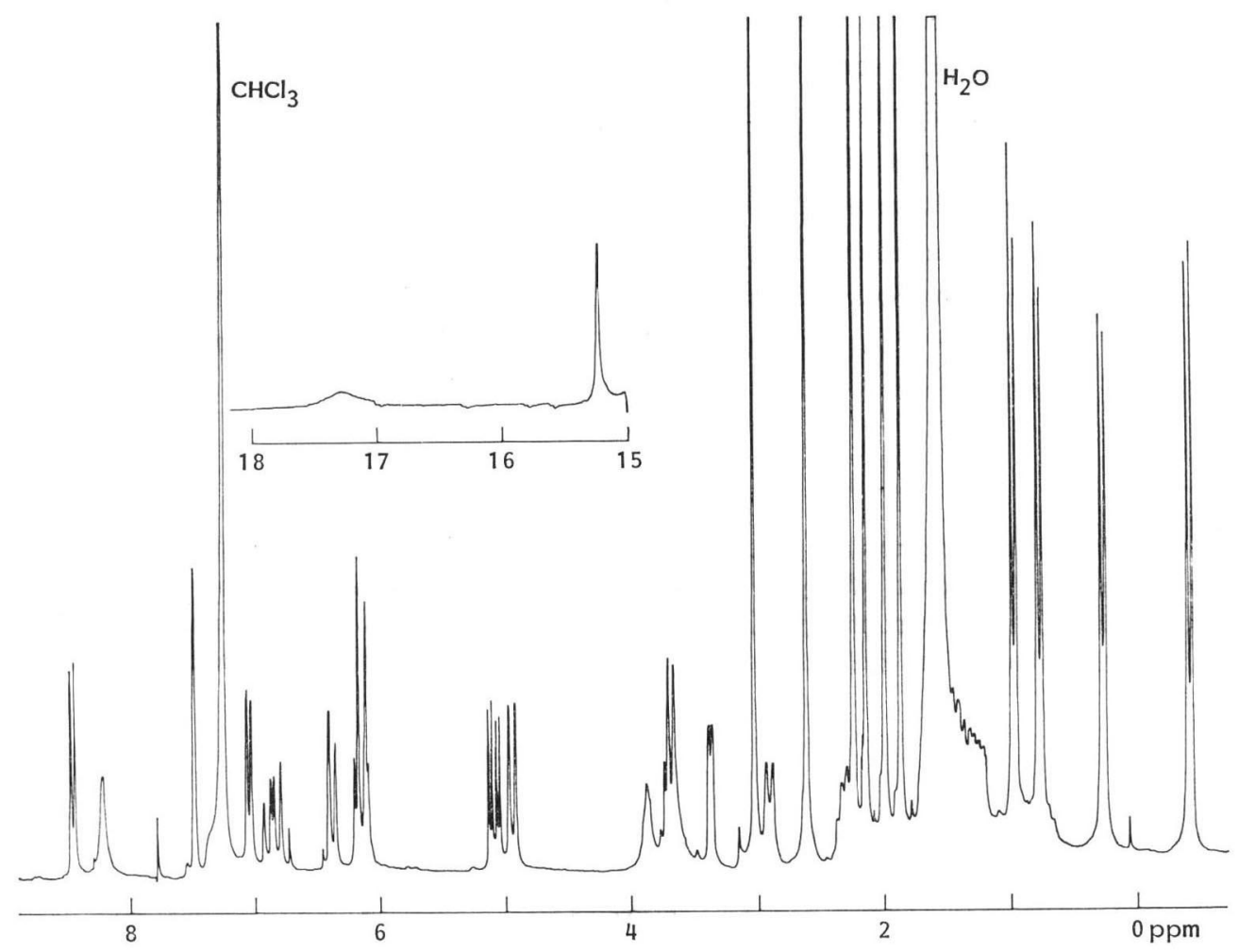

the chromophore rings, and perhaps due also to the positive charge on $\mathrm{N}_{1^{\prime}}{ }^{\text {, })}$. This downfield effect is stronger on $\mathrm{C}_{4^{\prime}}-\mathrm{H}$, which certainly lies in the plane of the chromophore rings, while the other pyridine protons must lie outside this plane.

\section{3-Pyridiniumbromide Rifamycin S (2-S)}

Unlike 2-SV, there is free rotation around $\mathrm{C}_{3}-\mathrm{N}_{1^{\prime}}$, and symmetric protons on the pyridinic ring have the same chemical shift. The dihedral angle $\mathrm{C}_{27}-\mathrm{C}_{28}$ is about $140^{\circ}$ and the amide carbonyl is transoid with respect to $\mathrm{C}_{2}-\mathrm{C}_{3}{ }^{8}$.

\section{4-Deoxy-4'-methylpyrido[1',2'-1,2]imidazo[5,4-c]rifamycin SV (6-SV)}

In $\mathrm{CDCl}_{3}$ solution chemical shifts vary with concentration in the range $0.01 \sim 10 \mathrm{~mm}$, while in $\mathrm{D}_{2} \mathrm{O}$ (conc $0.1 \mathrm{~mm}$ ) the spectral lines are very broad ${ }^{8}$. This peculiar behavior has been attributed to intermolecular interactions taking place in solution and involving the charged nitrogens and the phenolic hydroxyls. Therefore the spectrum in $\mathrm{CDCl}_{3}$ is discussed at a certain concentration, i.e. $0.1 \mathrm{~mm}$ (Fig. 2). In general, all values of chemical shifts and coupling constants lie quite close to the corresponding values of the other rifamycin SV derivatives examined ${ }^{8)}$, with the exception of $\mathrm{O}_{1} \mathrm{H}$ and $\mathrm{O}_{2} \mathrm{H}$, which in this compound are downfield shifted. The amide carbonyl is transoid with respect to $\mathrm{C}_{2}-\mathrm{C}_{3}$, and the dihedral angle $\mathrm{C}_{27}-\mathrm{C}_{28}$ is about $140^{\circ}{ }^{8)}$.

4-Deoxy-4'-methylpyrido[1',2'-1,2]imidazo[5,4-c]rifamycin S (6-S)

The spectrum in $\mathrm{CDCl}_{3}$ of this compound lacks the signal of the amide proton, thus indicating that 
the molecule is in an orthoquinonimine form. Unlike other rifamycin $\mathrm{S}$ derivatives ${ }^{8)}$, the signals of the protons bound to $\mathrm{C}_{17}, \mathrm{C}_{18}$ and $\mathrm{C}_{19}$, are no longer well resolved, but collapse into a narrow multiplet centered at $6.6 \mathrm{ppm}$; the coupling constant $\mathrm{C}_{10} \mathrm{H}-\mathrm{C}_{20} \mathrm{H}$, falls from $6.5 \sim 7.5 \mathrm{~Hz}$ to $4 \mathrm{~Hz}$, indicating a rotation of the angle $\mathrm{C}_{19}-\mathrm{C}_{20}$. Furthermore, the signals of the protons on $\mathrm{C}_{21}, \mathrm{C}_{22}, \mathrm{C}_{24}, \mathrm{C}_{28}, \mathrm{C}_{33}$ and $\mathrm{C}_{34}$ are all upfield shifted $\left(\mathrm{C}_{21} \mathrm{H}\right.$ from 3.9 to $\left.2.9 \mathrm{ppm}\right)$. The effects can be attributed mainly to the higher magnetic susceptibility of the enlarged chromophore system, as well as to the transformation of the amide group and the torsion around $\mathrm{C}_{10}-\mathrm{C}_{20}$. Under these conditions, it is no longer possible to assign the position of the amide carbonyl with respect to $\mathrm{C}_{2}-\mathrm{C}_{3}$ as a function of the chemical shift of $\mathrm{C}_{18} \mathrm{H}$. The downfield shift of $\mathrm{C}_{21} \mathrm{H}$ with respect to pyridine ${ }^{9)}$ can be attributed both to the positive charge on $\mathrm{N}_{1^{\prime}}$ and to the ring current effect ${ }^{10)}$. The dihedral angle $\mathrm{C}_{27}-\mathrm{C}_{28}$ is about $140^{\circ}{ }^{8}$.

\section{Conclusions}

By assuming that rifamycins are generally absorbed by passive diffusion, the presence of charged nitrogens in the pyridoimidazo rifamycin SV derivatives may be responsible for the impaired absorption of these drugs, since the contemporary presence of the phenolic hydroxyls means these drugs are ionized at all $\mathrm{pH}$ values of the gastroenteric tract, and are thus too polar to cross the lipoid membranes efficiently.

\section{Acknowledgment}

The authors thank M. VioLA for the drawings.

\section{References}

1) Marchi, E.; G. Mascellani, L. Montecchi, M. Brufani \& L. Cellai: L/105, a new semisynthetic derivative of rifamycin SV. Chemioterapia 27 (Supplement to No. 4):212, 1982

2) Dampier, M. F.; C.-W. Chen \& H. W. Whitlock, Jr.: Substituent effects on the solution conformation of rifamycin S. J. Am. Chem. Soc. 98: 7064 7069, 1976

3) Sensi, P.; R. Ballotta, A. M. Greco \& G. G. Gallo: Rifomycin. XV. Activation of rifomycin B and rifomycin O. Production and properties of rifomycin S and rifomycin SV. Il Farmaco, Ed. Sci. 16: 165 180,1961

4) Kump, W. \& H. Bickel: Zur Kenntniss von Rifamycin S. Reaktionen des chinoiden Nucleus. Helv. Chim. Acta 56: 2348 2377, 1973

5) Brufani, M.; L. Cellat, S. Cerrini, W. Fedeli, E. Marchi, A. Segre \& A. Vaciago: X-Ray crystal structure of 4-deoxy-3'-bromopyrido[1',2'-1,2]imidazo[5,4-c]rifamycin S. J. Antibiotics 37: 1623 1627, 1984

6) Cellai, L.; S. Cerrini, A. Segre, C. Battistoni, G. Cossu, G. Mattogno, M. Brufani \& E. Marchi: A study on structure-activity relationships in 4-deoxypyrido $\left[1^{\prime}, 2^{\prime}-1,2\right]$ imidazo[ $[5,4-c]$ rifamycin $\mathrm{SV}$ derivatives by ESCA and ${ }^{1} \mathrm{H}$ NMR. Mol. Pharmacol., in press (1985)

7) Mosby, W. L. \& R. J. Boyle: Reactions of 2,3-dichloro-1,4-naphthoquinone with 2-aminopyridine and related amines. J. Org. Chem. 24: 374 380, 1959

8) Cellai, L.; S. Cerrini, A. Segre, M. Brufani, W. Fedeli \& A. Vaciago: Comparative study of the conformations of rifamycins in solution and in the solid state by proton nuclear magnetic resonance and X-rays. J. Org. Chem. 47: 2652 2661, 1982

9) WÜtrich, K.: NMR in Biological Research: Peptides and Proteins. pp. 39 42, North-Holland, Amsterdam, 1976

10) Jackmann, L. M. \& S. Sternhell: Applications of NMR Spectroscopy in Organic Chemistry. 2nd. Ed., pp. $61 \sim 113$, Pergamon Press, Oxford, 1972 